\title{
PRINCIPLES OF MISTAKEPROOFING AND INVENTIVE PROBLEM SOLVING (TRIZ)
}

\author{
Iris D. Tommelein ${ }^{1}$
}

\begin{abstract}
To err is human but people can design and make systems that are less error-prone, and more fail-safe and defect-free than many are today. One such lean design practice is called mistakeproofing (poke yoke). It is integral to the Toyota Production System and successfully practiced in numerous industry sectors. Mistakeproofing is not as widelynor as intentionally practiced in the Architecture-Engineering-Construction (AEC) industry as it could be. To promote conceptual understanding and adoption, this paper presents 6 mistakeproofing principles. To further spur innovative mistakeproofing practices, it also presents the 40 principles of the Theory of Inventive Problem Solving (TRIZ). Mistakeproofing examples from the AEC industry demonstrate how these two sets of principles can be directly linked to rationalize existing mistakeproofing practices and, in addition, to potentially design "innovative" ones. As such, this paper supports the drive for industry innovation in developing products and processes of greater quality and thereby contribute to construction industry performance improvement.
\end{abstract}

\section{KEYWORDS}

visual management, mistakeproofing (mistake-proofing, mistake proofing), error proofing, poka yoke, Theory of Inventive Problem Solving, TRIZ

\section{INTRODUCTION}

To err is human. People can and, despite their best intentions, will make inadvertent errors (mistakes). Recognizing this reality while at the same time aiming to eliminate this source of bad variation, lean practitioners rely on mistakeproofing (also spelled "mistake-proofing" or "mistake proofing"). Mistakeproofing (translated from the Japanese word "poka yoke," a concept integral to the Toyota Production System) has been successfully practiced in numerous industry sectors. It can be practiced, likewise, in the Architecture-Engineering-Construction (AEC) industry.

Mistakeproofing is "the use of any automatic device or method that either makes it impossible for an error to occur or makes the error immediately obvious once it has occurred (ASQ 2019)." It is also known as error proofing or fail safing (these words too may also be spelled as a single word or with a hyphen). The objective of mistakeproofing is to reduce the likelihood that errors will occur and, should they occur anyway, to prevent that they turn into defects.

Where mistakeproofing has been used in other industry sectors (e.g., service sectors such as healthcare, e.g., Grout 2003, Godfrey et al. 2005) it has yielded significant

Professor, Civil and Envir. Engrg. Dept., Director of the Project Production Systems Laboratory (p2sl.berkeley.edu), Univ. of California, Berkeley, CA 94720-1712, USA, +1 510 643-8678, tommelein@berkeley.edu, orcid.org/0000-0002-9941-6596 
benefits. Reasonably one may therefore expect that the AEC industry will benefit from its use as well. Owners, designers, contractors, engineers, product manufacturerssimply: everyone needs to know what and where opportunities exist for mistakeproofing, to gauge what value may stem from it, and to sharpen their thinking about opportunities to mistakeproof what they do (processes) and make (products). Mistakeproofing is relevant and applies to products, steps in operations that make up processes, and projects small and large, simple and complex, and all sectors of the construction industry (e.g., Wood 1986, McDonald 1998).

In an early IGLC paper, dos Santos and Powell (1999) noted that "empirical evidences revealed that the sector makes little use of this approach at the present moment." About a decade later, Tommelein (2008) observed that it was still the case that "mistake proofing appears to not have been [...] systematically researched or practiced in the lean construction community" and proceeded by saying that "To raise awareness of opportunities provided by thinking with mistake proofing in mind as a means to build quality into project delivery, this paper summarizes the philosophy that underlies mistake proofing. Examples illustrate how mistake proofing applies to the work done within one specialty trade, how manufacturers and fabricators can design their products so they cannot be constructed defectively, and how architects and engineers may conceive of system designs that are less likely to fail during construction or in a product's life cycle." Now, another decade later, systematic research on mistakeproofing and its application in the AEC industry appears to still be scarce. Some related research has been conducted in the context of visual management (e.g., dos Santos et al. 1998, Moser and dos Santos 2003, Rocha et al. 2018) but a clear presentation of mistakeproofing principles and systematic means to design new practices is overdue.

With the latter in mind, this paper first offers some conceptual background and lays out 6 principles for mistakeproofing. Second, it offers background on the Theory of Inventive Problem Solving (TRIZ), developed to help spur innovative concept generation, and refers to the 40 TRIZ principles. Third, it presents mistakeproofing examples from the AEC industry to illustrate how these sets of principles can be directly linked to rationalize existing mistakeproofing practices and, in addition, potentially design "innovative" ones. The paper concludes by stressing the need to systematically drive industry innovation in developing products and processes of greater quality, and thereby contribute to construction industry performance improvement.

\section{MISTAKEPROOFING}

Mistakeproofing is an old concept. It is a practice related to autonomation ("jidoka" in Japanese), with origins going back at least to the late 1800s when Sakichi Toyoda devised a way to detect broken thread and automatically stop a loom to avoid making defective product. The mistakeproofing concept was described by Suzaki (1985) and Shingo (1986), who wrote the book Zero Quality Control. Claiming "Defects $=0$ is absolutely possible!" Shingo critiqued the use of statistical process control and was set on eliminating ad-hoc quality control (QC) (e.g., in construction, ad-hoc QC includes punch-list processes and rework that experienced practitioners all too often take for granted but nobody wants).

Shingo noted the need to clearly distinguish errors from defects, that is, to differentiate between causes and effects: "errors will not turn into defects if feedback 
and action take place at the error stage." Elimination of defects by mistakeproofing is done by reducing the possibility of errors occurring, by making errors-should they occur - easily detectable, and by mitigating their effects so they would not turn into defects. As a result, mistakeproofing reduces the need for inspection.

Mistakeproofing is based on 6 principles (e.g., Shingo 1986, Shimbun 1988, McMahon 2016) as illustrated in Figure 1 (after Fig. 1 in Godfrey et al. 2005, attributed to Prof. Takeshi Nakajo, redrawn and color-coded by Tommelein). These principles apply to the design of a product (e.g., Norman 1989, Taguchi and Clausing 1990) and related operations. They have an impact at different points in time, when different steps in the operation are performed. Colors in Figure 1 indicate the author's assessment of the desirability of the intervention. The range spans from dark green, the most desirable type of mistakeproofing, to red, the least desirable type - though still desirable!

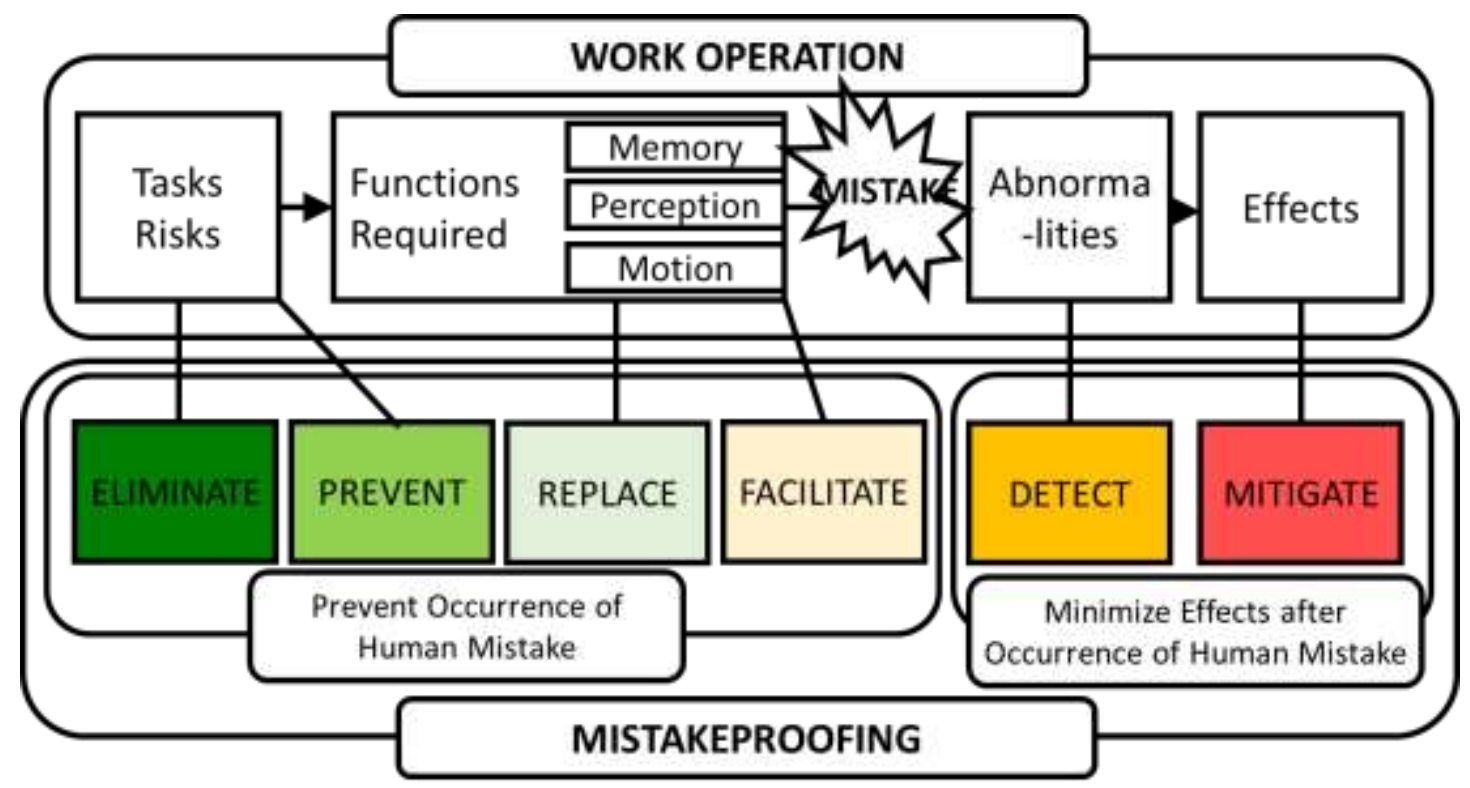

Figure 1: Mistakeproofing Principles Applied to Work Operations (after Figure 1 in Godfrey et al. 2005, attributed to Prof. Takeshi Nakajo, redrawn and color-coded by Tommelein)

While planning an operation before it starts, risks associated with the steps that make up the operation are identified and their possible occurence "designed out" so they will be avoided altogether. Mistakeproofing principles to achieve this are:

1. Elimination (paraphrased as "don't do it anymore") is to remove the possibility of an error occurring in a step by redesigning the product or operation so that the step (or associated product part) is no longer necessary.

2. Prevention ("make sure it can never be done wrong") is to design and engineer the product or operation so that it is impossible to make a mistake at all.

If the operation cannot be designed to guarantee elimination or prevention of the occurrence of errors, then consideration must be given to how errors may manifest themselves in the course of performing the operation. While performing a step in an operation, people involved can rely on their memory, perception, and motor skills to perform not only the step but also to avoid errors. Mistakeproofing principles to support people then are: 
3. Replacement ("use something better") is to substitute one operation with a more reliable operation to improve consistency.

4. Facilitation ("catch people's attention, help them make fewer mistakes") is to use various means (e.g., sensory input) to make steps easier to perform mistake-free.

If the operation can get to a point at which a mistake gets made, the mistakeproofing principle "detection" comes into play.

5. Detection ("notice what is going wrong and stop it") is to identify a mistake promptly so that a person can quickly correct it and thereby avoid that the error may turn into a defect.

Finally, if the ocurrance of a defect cannot be prevented, mistakeproofing can help avoid that the situation turns into a disaster, using the following principle:

6. Mitigation ("don't let the situation get too bad") is to minimize the effects of errors. Grout (2003) calls this "designing benign failures."

Mistakeproofing will be most effective when applied before a mistake occurs by elimination, prevention, replacement, or facilitation (Figure 1). However, should a mistake occur, it will still be beneficial to the performance of the operation overall to detect that occurrence and mitigate its impact.

These 6 mistakeproofing principles can readily be applied in the AEC industry. Tommelein and Demirkesen (2018) documented 30 examples of mistakeproofing practices in the AEC industry, selected from Tommelein's collection of more than 100. Categorization of those examples based on the 6 aforementioned principles indicates that AEC practitioners tend to resort to facilitation, detection, and mitigation significantly more so than to using principles that aim at designing potential mistakes "out." Methods are needed to systematically design more instances of mistakeproofing. The following section describes one such method.

\section{THEORY OF INVENTIVE PROBLEM SOLVING (TRIZ)}

Knowledge of the mistakeproofing principles will help people recognize practices already in use. Such recognition will inform new practices in that examples can be copied or extrapolated from one application to another. In addition to direct copying or extrapolation, other methods are available to mistakeproof existing products or processes, or to design an altogether new mistakeproofed-ones. The "Theory Inventive Problem Solving" or TRIZ serves as a means to this end (Cerit et al. 2014).

\section{DEFINITION OF TRIZ}

TRIZ is a Russian acronym, translated into English as the Theory of Inventive Problem Solving (TIPS). This theory was developed by Altshuller, a Russian patent officer who judged- and, from 1946 onward, studied principles to foster innovations (Altshuller 1984, 1997, 1999, Souchkov 2008 rev. 2015). Over a period of time, Altshuller and colleagues compiled not only 40 principles but also developed Algorithms for Inventive Problem Solving (ARIZ) (e.g., Altshuller 1999, Marconi 1998) and related methods to foster innovative thinking. In line with Ikovenko's (2005) suggestion that TRIZ could be used as a Lean Thinking tool and the application of TRIZ in construction (Teplitskiy 2005), the focus in this paper in on using TRIZ principles to rationalize existing as well as design new mistakeproofing examples. 


\section{PRINCIPLES OF TRIZ}

In the course of design, designers face requirements and constraints that often are contradictory, and must then negotiate tradeoffs. In the TRIZ context, designers speak of contradictions. To offer an example from Toyota, engineer Suzuki who spearheaded the Lexus program, became known for his uncompromising stance on seemingly conflicting design requirements (e.g., develop a car that can reach high top speeds, yet have low fuel consumption) known as "Suzuki's YETs" (Liker 2004 p. 43-50).

Altshuller (1999 pp. 287-289) compiled a set of 40 TRIZ principles that serve as a means to resolve contradictions and thereby spur innovative thinking. For brevity, these are not all replicated in this paper. Only 10 TRIZ principles (namely 2, 3.3, 4.1, 6.1, 11, $12,14,18,23.1$, and 32.1) are mentioned later in the examples provided. Readers can find all 40 in Altshuller's book (op. cit.) or, with minor adjustments in wording, on the TRIZ40 (n.d.) website.

Innovation using TRIZ principles is a four-step process to inspire thinking outside of the box. Figure 2 shows that it requires (1) a statement of a concern (problem), (2) abstraction to a more conceptual level, (3) followed by the application of a principle, and then (4) specialization to formulate a countermeasure (solution).

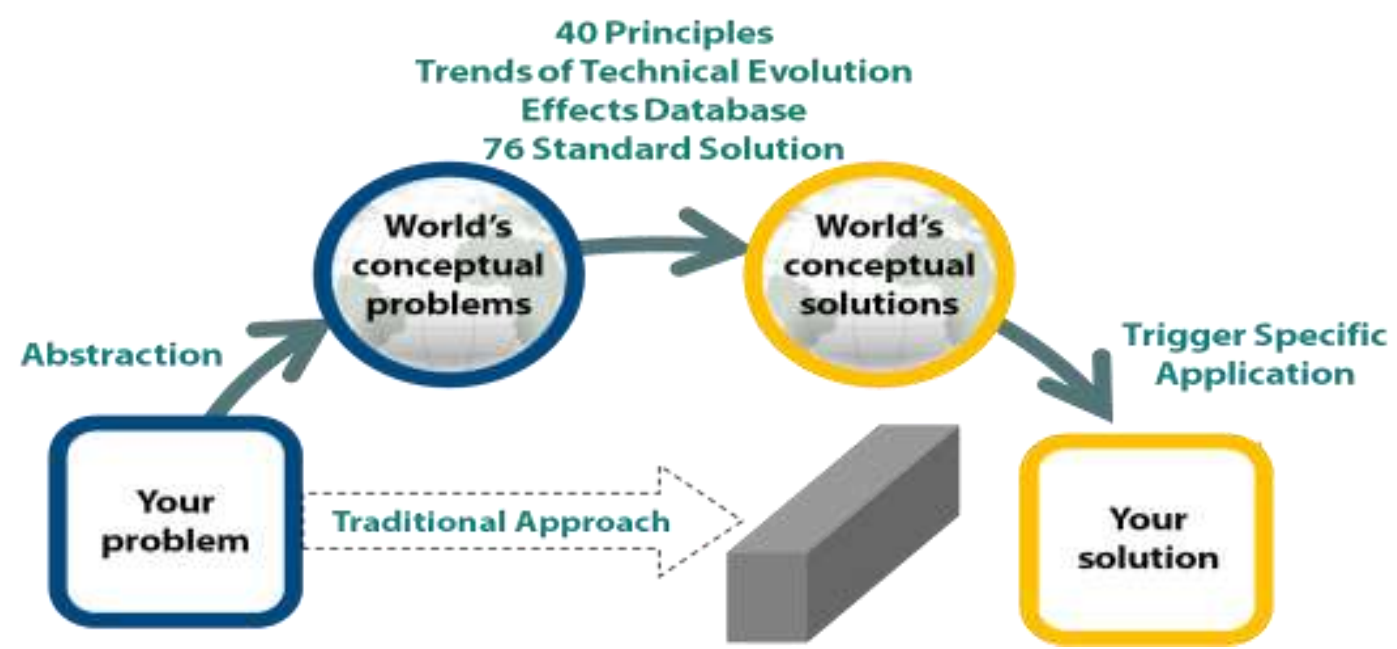

Figure 2: Prism of TRIZ Problem Solving Solutions (Oxford Creativity,

(upload.wikimedia.org/wikipedia/commons/thumb/a/a2/Prism_of_TRIZ_Oxford_Cre ativity.png/640px-Prism_of_TRIZ_Oxford_Creativity.png visited 18 Feb. 2019)

\section{AEC EXAMPLE APPLICATIONS OF MISTAKEPROOFING AND TRIZ PRINCIPLES}

With the mistakeproofing mind-set explained, 6 mistakeproofing principles presented, and reference to the 40 TRIZ principles available to rationalize innovations (in this case: means for mistakeproofing), the following examples (Figures 3 to 12) show how these two sets of principles can be directly linked to characterize existing mistakeproofing practices. Each example describes a situation where a concern exists for a mistake to happen. A photo illustrates the mistakeproofing practice and that practice is also described as the countermeasure. In addition, each example refers to one of the 6 colorcoded mistakeproofing principles and also to one of the 40 TRIZ principles that (conceivably) was applied. 


\begin{tabular}{|c|l|}
\hline $\begin{array}{c}\text { CONCERN: } \\
\text { Thage source: Tim Carter - } \\
\text { h-circular-saw-should-i-buy/ } \\
\text { visited 17 Feb. 2019 } \\
\text { worker's working range. } \\
\text { The cord attached to the tool and any extension } \\
\text { cords may get tangled or damaged in use, and } \\
\text { create a tripping hazard. } \\
\text { COUNTERMEASURE: Eliminate cord and } \\
\text { tripping hazard by using batteries to supply } \\
\text { electricity to power tool. } \\
\text { LIMITATION: Relative to corded tools, battery- } \\
\text { powered tools tend to have less power and are more } \\
\text { limited in capacity. }\end{array}$ \\
$\begin{array}{c}\text { Mistakeproofing Principle: } \\
\text { TRIZ Principle 2 Taking Out: Separate an interfering part or property from an } \\
\text { object, or single out the only necessary part (or property) of an object. }\end{array}$ \\
\hline
\end{tabular}

Figure 3: Two Nearly Identical Circular Saws: Corded and Cordless

\begin{tabular}{|l|l|}
\hline & $\begin{array}{l}\text { CONCERN: } \\
\text { E Electrical wires may get connected wrongly. } \\
\text { Electricians must work at elevation to wire } \\
\text { linear light fixtures, which is strenuous. } \\
\text { COUNTERMEASURE: } \\
\text { In the shop, install clips to end the wiring on each } \\
\text { fixture. Put on correctly, these clips can snap } \\
\text { together in only one way (asymmetry) so that the } \\
\text { wires will always be connected correctly. On site, } \\
\text { the electrician's installation work at elevation won't } \\
\text { take much time nor be as strenuous. }\end{array}$ \\
\hline $\begin{array}{l}\text { Image source: Finelite (2008). Estimator and Contractor Guide. } \\
\text { www.finelite.com/contractor/ContractorGd_m.pdf visited 22 April. }\end{array}$ \\
\hline $\begin{array}{l}\text { Mistakeproofing Principle: } \\
\text { TRIZ Principle } 4 \text { Asymmetry: }\end{array}$ \\
symmetrical to asymmetrical.
\end{tabular}

Figure 4: Connection Plug and Wiring of Linear Light Fixture

The methodology the author used was to assess each example and use judgment to classify it by principle. In fact, examples may illustrate multiple principles from each set of principles. The reader can expand on these examples further.

The examples are intended to help readers "learn to see" and recognize mistakeproofing practices in their everyday environment, so they can then leverage that ability to create their own mistakeproofing applications. 


\begin{tabular}{|c|c|}
\hline & $\begin{array}{l}\text { CONCERN: The cover for an opening that is } \\
\text { rectangular (e.g., a ground excavation), can be } \\
\text { turned sideways and fall into the opening. People } \\
\text { working underneath inside the opening would be in } \\
\text { harm's way. } \\
\text { COUNTERMEASURE: A manhole cover is } \\
\text { round because a round object cannot fall through a } \\
\text { circular opening of at least the same diameter, no } \\
\text { matter how it is positioned. }\end{array}$ \\
\hline \multicolumn{2}{|c|}{$\begin{array}{l}\text { Image source: McCarthy (2015-01-07) "Why Are Manhole Covers Round?" } \\
\text { mentalfloss.com/article/60929/why-are-manhole-covers-round visited } 19 \text { Oct. } 2016 .\end{array}$} \\
\hline Mistakeproofing Principle: & \begin{tabular}{l|l} 
PREVENT & \\
\end{tabular} \\
\hline TRIZ Principle $14 \mathrm{~S}$ & $\begin{array}{l}\text { y (Curvature): Instead of using rectilinear parts, } \\
\text { ones... }\end{array}$ \\
\hline
\end{tabular}

Figure 5: Round Manhole Cover

\begin{tabular}{|l|l|}
\hline & $\begin{array}{l}\text { CONCERN: Mounting a towel bar on a wall } \\
\text { requires accurate measurement of the spacing } \\
\text { between screws. } \\
\text { COUNTERMEASURE: The towel bar packaging } \\
\text { acts as a template to facilitate installation by } \\
\text { identifying the location of the drill holes, thereby } \\
\text { eliminating the need to measure the distance } \\
\text { between screws and then marking the location } \\
\text { before drilling holes. } \\
\text { The template is held level and taped to the wall. } \\
\text { The location of the 4 drill holes needed are }\end{array}$ \\
$\begin{array}{c}\text { Image source: Brittany } \\
\text { Towel Bar Securely. Www. } \\
\text { prettyhandygirl. com /how-to- } \\
\text { install-towel-bar-securely/ } \\
\text { visited 1 Nov. 2017 }\end{array}$ & $\begin{array}{l}\text { illustrated on the template without requiring any } \\
\text { additional work. Use of templates makes it } \\
\text { significantly easier and faster to complete the work. }\end{array}$ \\
\hline $\begin{array}{c}\text { Mistakeproofing Principle: } \\
\text { TRIZ Principle } 6 \text { Universality: 6.1 Make a part or object perform multiple } \\
\text { functions; eliminate the need for other parts. }\end{array}$ \\
\hline
\end{tabular}

Figure 6: Towel Bar Installation Template 


\begin{tabular}{|l|l|}
\hline & $\begin{array}{l}\text { CONCERN: } \\
\text { Welders must bend or reach over and twist their } \\
\text { bodies to access connections to be welded. } \\
\text { Weld material runs down due to gravity. } \\
\text { COUNTERMEASURE: "ConXtech is the first } \\
\text { manufacturing facility [...] to weld, in a production } \\
\text { environment, Hollow Structural Steel (HSS) } \\
\text { columns entirely in the horizontal position." } \\
\text { Welder works at ergonomically comfortable } \\
\text { height and can turn by hand the column to the } \\
\text { right position. } \\
\text { Weld material is deposited horizontally. }\end{array}$ \\
\hline Image source: www.prweb.com/releases/conxtech/ladbs-approved/ \\
prweb10762433.htm visited 28 Feb. 2019
\end{tabular}

Figure 7: Rotating Jig and Clamps to Hold Welded Steel Element

\begin{tabular}{|l|l|}
\hline & $\begin{array}{l}\text { CONCERN: when using white paint to paint over } \\
\text { a white ceiling, it is hard to see which areas have } \\
\text { already been painted, so application may be uneven. } \\
\text { COUNTERMEASURE: Additives to the paint } \\
\text { make the white paint look pink for as long as it is } \\
\text { wet. When it dries, it gradually turns white. } \\
\text { Image source: Glidden® EZ Track Ceiling Paint, } \\
\text { kk.org/cooltools/ glidden-ceiling/ visited } 3 \text { Oct. } \\
2017\end{array}$ \\
\hline $\begin{array}{l}\text { Mistakeproofing Principle: } \\
\text { TRIZ Principle 32 Color changes: } 32.1 \text { Change the color of an object or its } \\
\text { external environment. }\end{array}$
\end{tabular}

Figure 8: Color-changing Paint 


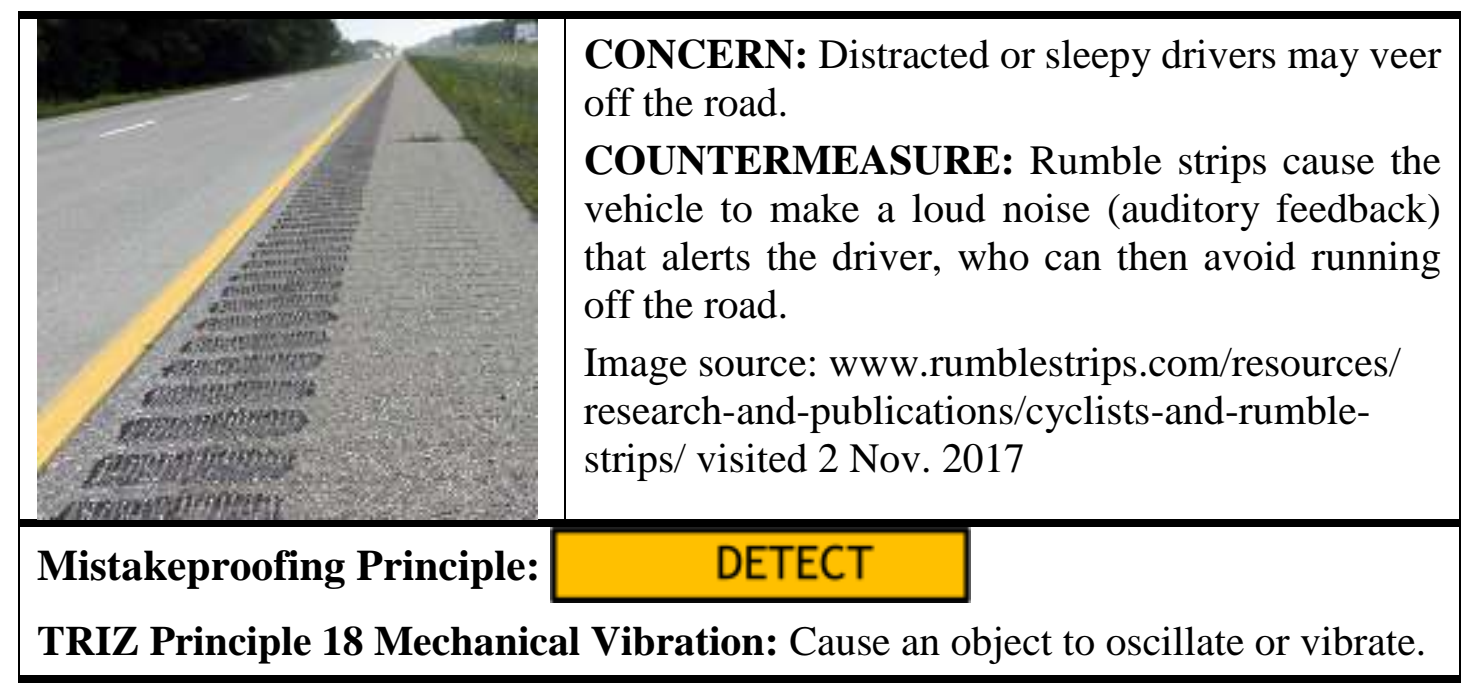

Figure 9: Rumble Strip

\begin{tabular}{|c|c|}
\hline & $\begin{array}{l}\text { CONCERN: Structural bolts must have the proper } \\
\text { pretension in order to be functional. This tension is } \\
\text { achieved by torqueing the bolt however torque is } \\
\text { not a reliable indicator of tension. } \\
\text { COUNTERMEASURE: Squirter DTIs are } \\
\text { compressible washers that show when a bolt } \\
\text { reaches its target tension, independent of torque, by } \\
\text { expressing orange-colored material. } \\
\text { Image source: Myhrum, B. (2010). "Simple QA } \\
\text { for Wind Turbine Bolts." Windpower, } \\
\text { www.windpowerengineering. com/ } \\
\text { construction/simple-qa-for-wind-turbine-bolts/ }\end{array}$ \\
\hline Mistakeproofing Principle: & DETECT \\
\hline
\end{tabular}

Figure 10: Tension Bolt

TRIZ principles (and ARIZ methodology) can also be used to design innovative mistakeproofing practices. Imagine designing a nail gun with a contact sensor that also, like SawStop (Figure 12), gauges the conductivity of the surface it touches. The nail gun should fail to engage upon contact with a person.

\section{CONCLUSIONS}

The principles of mistakeproofing have practical and useful application in the AEC industry. While perhaps not so obvious to the untrained eye, quite a few such applications already exist. AEC practitioners should learn to see them. The practice of mistakeproofing construction, itself, needs to be made more visible. Documentation of existing practices will inspire greater adoption. The systematic adoption of 
mistakeproofing principles is bound to help improve quality performance in the shortand long-term as it has across the board in other industries.

The need to mistakeproof everyday products and processes may seem obvious - or hopefully will appear obvious in hindsight. The generation of new ways to mistakeproof product designs, and steps in operations that make up processes can be supported by drawing on the 40 principles of TRIZ. TRIZ takes a scientific approach to foster innovative thinking and offers methods that can be taught. It should be considered for inclusion in any mistakeproofing curriculum.

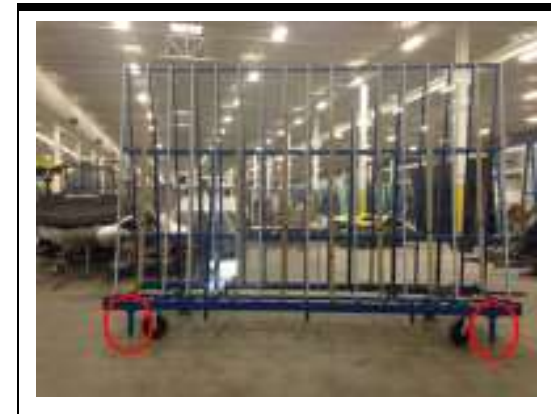

CONCERN: Cart (as shown, loaded with $\sim 1,600$ $\mathrm{kg}$ or 3,500 pounds of glass) may tilt over or collapse due to wheel/caster failure, and crush or kill a worker.

COUNTERMEASURE: Added a "dead man" concept (cicled in red) to each of the 4 corners of the fabricated cart to prevent cart from tilting over or collapsing in case of wheel/caster failure.

Image source: Stoker, I. and Stearns, L. (2017). "Harmon Glass Handling KaizenReport Out (Event Dates: 1/12 to 1/14)." Harmon, Inc. Mfg. Facility, Cincinnati, OH, 30 Nov. 2017; Powerpoint slides provided by Chad Hoffmann, 23 pp.

\section{Mistakeproofing Principle: MITIGATE}

TRIZ Principle 3 Local Quality: 3.3 Make each part of an object fulfill a different and useful function.

Figure 11: Wheeld Cart with "Dead Man” Legs

\begin{tabular}{|c|c|}
\hline 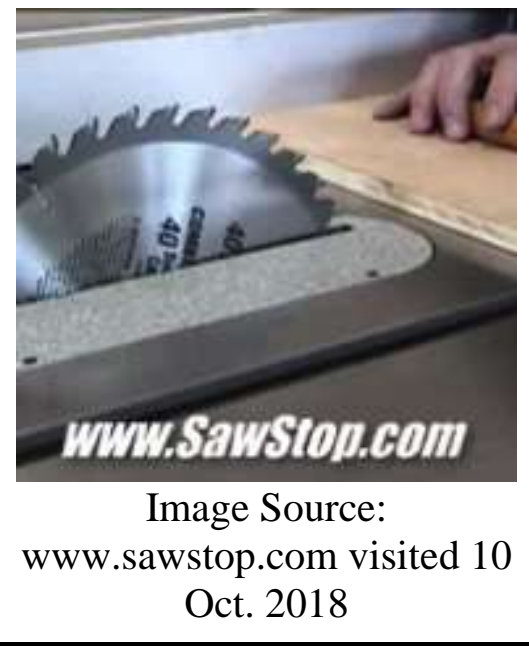 & $\begin{array}{l}\text { CONCERN: People use their hands to push } \\
\text { material and cut it with the table saw. Their hand } \\
\text { may get caught by the blade. } \\
\text { Table saws have blade guards to reduce the } \\
\text { likelihood of a hand getting caught, but workers } \\
\text { may find these to be impractical and remove them. } \\
\text { COUNTERMEASURE: "The SawStop saw } \\
\text { detects contact with skin. The blade carries a small } \\
\text { electrical signal, which the safety system } \\
\text { continually monitors. When skin contacts the blade, } \\
\text { the signal changes because the human body is } \\
\text { conductive. The change to the signal activates the } \\
\text { safety system." }\end{array}$ \\
\hline Mistakeproofing Principle: & MITIGATE \\
\hline
\end{tabular}

Figure 12: Table Saw Stop 
By presenting sets of principles for mistakeproofing as well as for innovating using TRIZ, and demonstrating how these relate to industry-specific examples of mistakeproofing, this paper aims to encourage broader awareness and use of mistakeproofing in AEC education and practice. It supports the drive for industry innovation in developing products and processes of greater quality and thereby contribute to construction industry performance improvement.

\section{ACKNOWLEDGMENTS}

The author owes thanks to her students, colleagues, and industry practitioners who over the course of many years have suggested examples of mistakeproofing, only very few of which made it into this paper. The study relating mistakeproofing to TRIZ was made possible by member contributions to the Project Production Systems Laboratory (P2SL) at UC Berkeley, and by CPWR (The Center for Construction Research and Training) through cooperative agreement number U60-OH009762 from the National Institute of Occupational Safety and Health (NIOSH). This paper's contents are solely the responsibility of the author and do not necessarily represent the official views of members of P2SL, of the CPWR, or NIOSH.

\section{REFERENCES}

Altshuller, G.S. (1984). Creativity as an Exact Science. The Theory of the Solutions of Inventive Problems. Translated from Russian by A. Williams, Studies in Cybernetics: 5, Gordon and Breach Sci. Pubs., NY, 319 pp.

Altshuller, G. (1997). 40 Principles: TRIZ Keys to Technical Innovation. Translated from Russian by L. Shulyak and S. Rodman, Worchester, MA: Technical Innovation Center, $141 \mathrm{pp}$.

Altshuller, G. (1999). The Innovation Algorithm - TRIZ Systematic Innovation and Technical Creativity. Translated from Russian by L. Shulyak and S. Rodman, Worchester, MA: Technical Innovation Center, $312 \mathrm{pp}$.

ASQ (2019) https://asq.org/quality-resources/mistake-proofing visited 18 Feb. 2019.

Cerit, B., Küçükyazıcı, G., and Şener, D. (2014). "TRIZ: Theory of Inventive Problem Solving and Comparison of TRIZ with the other Problem Solving Techniques." Balkan J. of Electr. and Computer Engineering, 2 (2) 66-74.

dos Santos, A.D. and Powell, J. (1999). "Potential of Poka-Yoke Devices to Reduce Variability in Construction." Proc. $7^{\text {th }}$ Ann. Conf. Int'l. Group for Lean Constr., Berkeley, CA, USA, 26-28 July, pp. 51-62.

dos Santos, A., Powell, J., Sharp, J., and Formoso, C.T. (1998). "Principle of transparency applied in construction." Proc. $6^{\text {th }}$ Ann. Conf. Int'l. Group for Lean Construction, Guaruja, Brazil.

Godfrey, A.B., Clapp, T.G., Nakajo, T., and Seastrunk, C.S. (2005). “Application of healthcare-focused error proofing: principles and solution directions for reducing human errors." Proc. ASQ World Conf. Qual. and Impr., Seattle, WA, pp. 335-340.

Grout, J.R. (2003). "Preventing medical errors by designing benign failures." Joint Comm. J. on Quality and Safety, 29 (7) 354-362.

Ikovenko, S. (2005). "TRIZ as a Lean Thinking Tool." The TRIZ J., 7 Feb., trizjournal.com/triz-lean-thinking-tool/

Liker, J.K. (2004). The Toyota Way: 14 Management Principles from the World's Greatest Manufacturer. McGraw-Hill Education, 330 pp. 
Marconi, J. (1998). "ARIZ: The Algorithm for Inventive Problem Solving An Americanized Leaning Framework." The TRIZ J., April, www.trizjournal.com/archives/1998/04/d/

McDonald, M.J. (1998). Quality Prediction and Mistake Proofing: An LDRD Final Report. Sand- 98-0557, Sandia National Laboratories, Albuquerque, NM, 32 pp. www.osti.gov/servlets/purl/650152 visited June 15, 2016.

McMahon, T. (2016). "Six Principles of Mistake Proofing." A Lean Journey, 20 July 2016, www.aleanjourney.com/2016/07/six-principles-of-mistake-proofing.html.

Moser, L. and dos Santos, A. (2003). "Exploring the role of visual controls on mobile cell manufacturing: A case study on drywall technology." Proc. $11^{\text {th }}$ Ann. Conf. Int'l. Group for Lean Construction, Blacksburg, VA.

Norman, D.A. (1989). The design of everyday things. New York: Doubleday.

Rocha, C.G.D., Tezel, A. , Talebi, S., and Koskela, L. (2018). "Product Modularity, Tolerance Management, and Visual Management: Potential Synergies." Proc. $26^{\text {th }}$ Ann. Conf. Int'l. Group for Lean Constr., Chennai, India, 18-20 July, pp. 582-592.

Shimbun, K.N. (1988). Poka-Yoke: Improving Product Quality by Preventing Defects. Nikkan Kogyo Shimbun/Factory Magazine, Productivity Press, Portland, OR.

Shingo, S. (1986). Zero Quality Control: Source Inspection and the Poka-Yoke System. Portland, Oregon: Productivity Press.

Souchkov, V. (2008, revised 2015). "A Brief History of TRIZ." www.xtriz.com/BriefHistoryOfTRIZ.pdf visited 30 Jan. 2017.

Suzaki, K. (1985). "Japanese Manufacturing Techniques: Their Importance to US Manufacturers." J. of Business Strategy, 5 (3) 10-19.

Taguchi, G. and Clausing, D. (1990). "Robust Quality." Harvard Bus. Rev. Jan.-Feb., 65-75.

Teplitskiy, A. (2005). "Application of 40 Inventive Principles in Construction." The TRIZ J., triz-journal.com/application-40-inventive-principles-construction/

Tommelein, I.D. (2008). "'Poka Yoke' or Quality by Mistake Proofing Design and Construction Systems." In Tzortzopoulos, P. and Kagioglou, M. (Eds.) Proc. $16^{\text {th }}$ Ann. Conf. Int'l. Group for Lean Constr. (IGLC 16), 16-18 July, Manchester, UK.

Tommelein, I.D. and Demirkesen, S. (2018). Mistakeproofing the Design of Construction Processes Using Inventive Problem Solving (TRIZ). CPWR Small Study No. 16-3-PS, CPWR, Silver Spring, MD, 57 pp. Online at www.cpwr.com/sites/default/files/publications/Tommelein-mistakeproofingconstruction-process.pdf

TRIZ40 (n.d.). The 40 TRIZ Principles. www.triz40.com/aff_Principles_TRIZ.php visited 10 March 2017.

Wood, R.E. (1986). "Task Complexity: Definition of the Construct.” Organizational Behavior and Human Decision Processes, 37:37- 60. 